\title{
Do we know the optimal management of a torn anterior cruciate ligament of the knee?
}

\author{
Dizde yırtık ön çapraz bağın en uygun tedavisini biliyor muyuz?
}

\author{
O. Şahap Atik, M.D. \\ Department of Orthopedics and Traumatology, Medical Faculty of Gazi University, Ankara, Turkey
}

Reconstruction of the anterior cruciate ligament is not a prerequisite for restoring muscle function. ${ }^{[1]}$ However, restoring muscle function is a prerequisite for conservative or surgical treatment of the torn anterior cruciate ligament (ACL).$^{[1,2]}$

In young and active adults with acute ACL tears, Frobell et al. ${ }^{[2]}$ showed that rehabilitation plus early ACL reconstruction was not superior to rehabilitation plus optional delayed ACL reconstruction. The latter strategy substantially reduced the frequency of surgical reconstructions.

However, Mather et al. ${ }^{[3]}$ reported a costeffectiveness analysis of the timing of ACL reconstruction using the data exclusively from the KANON trial, MOON cohort, and national average reimbursement and revealed that early ACL reconstruction was more effective (with improved QALYs) at a lower cost than rehabilitation plus optional delayed ACL reconstruction.

Hence, this question arisses: What is the optimal timing of ACL reconstruction? High-level athletes frequently request surgery as soon as possible to return to sports, whereas individuals who are not involved with physically demanding activities may ask for a delay surgery. ${ }^{[3]}$ Probably, a reasonable answer lies in the fact of patient-based medicine for an effective treatment of ACL and prevention of osteoarthritis. ${ }^{[4]}$

\section{REFERENCES}

1. Atik OS. Is reconstruction of the anterior cruciate ligament a prerequisite for restoring muscle function? Eklem Hastalik Cerrahisi 2009;20:125-6.

2. Frobell RB, Roos EM, Roos HP, Ranstam J, Lohmander LS. A randomized trial of treatment for acute anterior cruciate ligament tears. N Engl J Med 2010;363:331-42.

3. Mather RC 3rd, Hettrich CM, Dunn WR, Cole BJ, Bach BR Jr, Huston LJ, et al. Cost-effectiveness Analysis of Early Reconstruction Versus Rehabilitation and Delayed Reconstruction for Anterior Cruciate Ligament Tears. Am J Sports Med 2014. [Epub ahead of print]

4. Atik OS. Is subchondral bone the crucial point for the pathogenesis and the treatment of osteoarthritis? Eklem Hastalik Cerrahisi 2014;25:1.

\footnotetext{
- Correspondence: O. Şahap Atik, M.D. Gazi Üniversitesi Tıp Fakültesi Ortopedi ve Travmatoloji Anabilim Dalı, 06500 Beşevler, Ankara, Turkey. Tel: +90 312 - 2025528 Fax: +90 312 - 2129008 e-mail: satikmd@gmail.com
} 